\title{
Table of international instruments
}

Budapest Convention on the Contract for the Carriage of Goods by

Inland Waterway, 2000

(CMNI) 27, 76, 135, 166, $168,175,175,179,192,193$, 311

Convention on the Contract for the International Carriage of Goods by Road, 1956 (CMR) ..... 8, 25, 27, 44, 45, 49, 55, 63, 66, 66, 76, 87, 116, 126, 130, 135, 166, 168, 169, 170, 171, 172, 173, 175, 179, 190, 191, 192, 193, 258, 282, 287, 290, 292, 293, 296, 297, 306, 311, 314

Convention on Limitation of Liability for Maritime Claims, 1976 (LLMC) 86,177

Convention for the Unification of Certain Rules Relating to International Carriage by Air, 1929 (Warsaw Convention) .... 8, 26, 55, 76, 117, 127, 130, 131, 149, 150, 151, 160, 170, 257, 261, 262, 263, 264, 269, 270, $272,309,310$

Convention for the Unification of Certain Rules for International Carriage by Air, 1999 (Montreal Convention) $8,9,26,44,55$, 76, 117, 135, 150, 151, 166, 169, 174, 175, 179, 192, 193, 248, 257, 260, 261, 262, 263, 264, 265, 266, 269, 270, 271, 273, 274, 276, 277, 278, 279, 282, 294, 295, 310, 312

International Convention for the Unification of Certain Rules of Law Relating to Bills of Lading,
1924 (Hague Rules) ... 8, 14, 16, $17,18,19,22,24,26,37,42$, 76, 113, 115, 123, 127, 129, 132, 136, 177, 186, 187, 188, 189, 203, 204, 206, 219, 220, 222, 301, 309

Protocol to Amend the International Convention for the Unification of Certain Rules Relating to Bills of Lading 1924, 1968

(Hague-Visby Rules) ... 7, 8, 19, 20, 21, 22, 23, 24, 37, 42, 53,

76, 113, 115, 127, 128, 135, 136, $147,148,149,153,155,159$, $161,169,178,179,186,187$, 188, 189, 206, 207, 208, 209, 210, 212, 217, 219, 220, 224, 301, 309

UN Convention on Contracts for the International Sale of Goods, 1980 (CISG) ..... 74, 76, 88, 93, 103, 105, 120, 182, 200, 286, 302

UN Convention on Contracts for the International Carriage of Goods Wholly or Partly by Sea 2008, UN Doc. A/RES/63/122

(Rotterdam Rules) .... 5, 6, 7, 8, 9, 10, 61, 67, 68, 77, 108, 133, 134, 135, 139, 140, 141, 143, $144,145,146,147,148,150$, $151,152,153,154,165,157$, $158,160,161,162,164,165$, 166, 167, 168, 169, 171, 173, 174, 175, 176, 179, 180, 181, 182, 194, 197, 198, 199, 200, 202, 203, 205, 206, 207, 208, 209, 210, 211, 212, 214, 222, 223, 224, 225, 226, 227, 228, 
229, 230, 231, 233, 234, 236, 237, 280, 290, 293, 294, 295, 296, 297, 299, 300, 301, 302, 303, 304, 305, 306, 307, 310, $311,312,313,314,315,316$, 317

UN Convention on International

Multimodal Transport of Goods, 1980 (Multimodal

Convention) $36,39,40,41$, $43,44,46,49,50,54,58,62$, $67,77,113,135,141,146,148$, 160, 161, 163, 166, 179, 193, 194, 198, 304, 305, 307

UN Convention on the Carriage of Goods by Sea, 1978 (Hamburg Rules) 7, 8, 16, 21, 24, 39, 40, 42, 76, 116, 125, 135, 136, 144, 147, 148, 149, 151, 159, 167, 179, 180, 181, 182, 189, 190, 193, 195, 196, 198, 199, 203, 206, 207, 208, 210, 222, 223, 301, 303, 305, 305, 308, 309
UN Vienna Convention on the Law of Treaties, 1969 (Vienna Convention or VCLT) .... 96, 97, 122, 125, 127, 128, 130, 168, 199, 277, 295

UNCTAD/ICC Rules for Multimodal Transport Documents, 1992 .... 41, 49, 162

Uniform Rules Concerning the Contract for International Carriage of Goods by Rail (CIM), Appendix $B$ to the Convention Concerning International Carriage by Rail (COTIF), May 1980 and Protocol to amend CIM-COTIF, 1999 ..... 24, 26, 27, 44, 55, 76, 87, 116, 135, 166, 168, 169, 174, 179, 191, 193, 195, 282, 292, 293, 296, 314

Cape Town Convention on International Interests in Mobile Equipment, 2001 (Cape Town Convention) .... 10, 76, 89, 102, 108, 109, 110, 111, 302, 304, 